\title{
Flowering, a Critical Phenological Stage as a Limiting Factor for Almond Native Ecotypes Cultivation in Eastern Morocco
}

\author{
Reda Melhaoui, Malika Abid, Atika Mihamou, Marianne Sindic ${ }^{1}$, \\ Hana Serghini Caid, Ahmed Elamrani*
}

LBPM Laboratory, Faculté des Sciences, Université Mohammed Premier, BP 717, Oujda 60000, Morocco,

${ }^{1}$ QSPA Laboratory, Gembloux Agro Bio-Tech, Université de Liege, Gembloux 5030, Belgium

*Correspondence to:

Elamrani A,

Tel: $+212-661431433$

Fax: +212-536-500-601

E-mail: ahmed.elamrani@gmail.com

Received July 27, 2017

Revised September 7, 2017

Accepted September 8, 2017
This study concerns (i) Botanical characterization of local almond ecotype named "Beldi" based on flowering period and flowers color measurements (ii) Chemical characterization of almond oil such as acidity and peroxide index and specific UV absorbance values (K232 $\&$ K270). The color results of 100 flowers analyzed by chromameter shows two different color categories. The first is very light pink to whitish $\left(\mathrm{L}^{*}=81.58, \mathrm{a}^{*}=7.43, \mathrm{~b}^{*}=8.06\right)$. The second is a dark pink $\left(\mathrm{L}^{*}=71.64, \mathrm{a}^{*}=18.34, \mathrm{~b}^{*}=4.97\right)$ with a difference in color between the two categories $\Delta \mathrm{E}=15.07$. Compared to Ferragnes/Ferraduel varieties, Beldi almond kernel has almost a comparable oil yield but different acidity and peroxide values which are $0.81 \%$, $8.12 \mathrm{meq} / \mathrm{O}_{2} / \mathrm{kg}$ and $0.40 \%, 16.39 \mathrm{meq} / \mathrm{O}_{2} / \mathrm{kg}$ respectively.

Key Words: Almond, Flowers color, Almond oil

\section{INTRODUCTION}

Almond is the most important nut crops in Morocco with an area of $151 \mathrm{kha}$ and an average production of 99,000 tons (Houmy et al., 2016; MAPM, 2014). Almond Branch in eastern Morocco is supported by a Belgium program for agriculture and rural development (PROFAO 2011-2017). The aim of this project is to expand the growing area of the almond tree by planting 6,000 ha of new orchards and by installing new units for crushing almonds in shell. Ferragnes/ Ferraduel $(\mathrm{F} / \mathrm{F})$ is the main couple of new introduced varieties due to their late blooming in March permitting to escape the adverse effects of January and February frosts.

Currently, this region benefits from another project which is considered a continuation of the PROFAO and aims to develop the almond sector by the characterization of cultivated varieties and the valorization of their final products. Thus this preliminary study concerns (i) the observation of two biological parameters of local ecotypes "Beldi" which are typically considered to be early flowering almond trees. (ii) Due to their small size and narrow shape, these local almond nuts are mainly used to produce almond oils for cosmetic uses. Thus because the fruits of these Beldi almond ecotypes are mainly used for almond's oil extraction, we compare the oils of these Beldi almonds to those of the newly introduced varieties "Ferragnes/Ferraduel".

\section{MATERIALS AND METHODS}

\section{Flower Color}

Color is a distinctive characteristic of plant species used to distinguish between different species varieties and also to evaluate fruit maturity and quality (Wu \& Sun, 2013). The study aimed to characterize the local almond ecotype named Beldi by comparing color of the flowers according to the system CIE $L^{\star} a^{\star} b$ The color measurements have been done using a chromameter C-410. CIELAB color space diagram (Fig. 1) as described by Liu et al. (2014) shows the following parameters. $L^{*}$ axis indicates the lightness of a color; $a^{*}$ axis is the ratio redness/greenness; $b^{*}$ axis is the ratio blueness/ yellowness. The ratio of the $\mathrm{a}^{\star}$ value and the $\mathrm{b}^{\star}$ value defines an angle which quantifies one of the hue $(\mathrm{H})$, (e.g. red,

(a) This is an open-access article distributed under the terms of the Creative Commons Attribution Non-Commercial License (http://creativecommons.org/licenses/by-nc/4.0) which permits unrestricted noncommercial use, distribution, and reproduction in any medium, provided the original work is properly cited.

Copyrights @ 2017 by Korean Society of Microscopy 


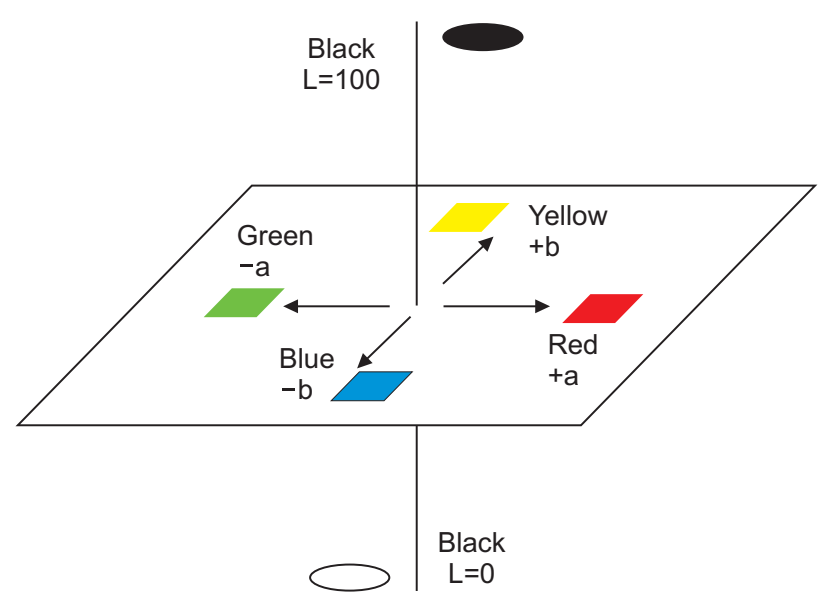

Fig. 1. CIELAB color space diagram.

Table 1. Main stages of flowering (Stage 6), according to the BBCH scale

\begin{tabular}{ll}
\hline 60 & The first flowers are open \\
61 & Beginning of blooming: almost 10\% of open flowers \\
62 & $20 \%$ of open flowers \\
63 & $30 \%$ of open flowers \\
64 & $40 \%$ of open flowers \\
65 & Full bloom: at least $50 \%$ of open flowers, first petals fall \\
67 & The flowering is completed: most petals have fallen \\
69 & Blooming end: all petals have fallen \\
\hline
\end{tabular}

$\mathrm{BBCH}$, Biologische Bundesanstalt, Bundessortenamt und CHemische Industrie.

orange, green). The chroma (C) is the distance from the central axis and is a measure of the vividness of a color (Van Eck \& Franken, 1994). The color system as recognized by the "Commission International de l'Eclairage" is chosen because its color space is more symmetrical than other color systems (Van Eck \& Franken, 1994; Wyszecki \& Stiles, 1982).

The different parameters $\left(\mathrm{L}^{\star}, \mathrm{a}^{\star}, \mathrm{b}^{\star}, \mathrm{H}^{\circ}, \mathrm{C}\right)$ are calculated from more than 100 collected flower of the ecotype Beldi in the area of Sidi Bouhria $\left(34^{\circ} 44^{\prime} 13.6^{\prime \prime} \mathrm{N}, 002^{\circ} 20^{\prime} 15.0^{\prime \prime} \mathrm{W}\right)$, in order to distinguish sub-varieties on the basis of color of flowers and period of flowering.

\section{Phenological Study of Flowering}

The aim is to indicate the different stages of flowering in order to determine the flowering period of each "Beldi" ecotypes and $\mathrm{F} / \mathrm{F}$. The flowering is characterized according to the BBCH scale (Table 1) which is used to identify the phenological development stages of a plant, with an uniform coding and description system (Lancashire et al., 1991).

\section{Characterization of Almond Oils}

Small size, narrow shape or damaged almond kernels of Beldi and F/F were triturated using a mechanical oil press. Almond
Table 2. Color parameters of flowers (whitish and pinkish flowers) of two Beldi almond ecotypes

\begin{tabular}{lcc}
\hline & \multicolumn{2}{c}{ Mean values of color parameter } \\
\cline { 2 - 3 } & $\begin{array}{c}\text { Group 1 with } \\
\text { whitish flowers }\end{array}$ & $\begin{array}{c}\text { Group 2 with } \\
\text { pinkish flowers }\end{array}$ \\
\hline $\mathrm{L}^{*}$ (lightness) & $81.58 \pm 1.07$ & $71.64 \pm 0.45$ \\
$\mathrm{a}^{*}$ (redness) & $7.43 \pm 0.35$ & $18.34 \pm 0.79$ \\
$\mathrm{~b}^{*}$ (yellowness) & $8.06 \pm 0.65$ & $4.97 \pm 0.28$ \\
$\mathrm{H}$ (hue) & $47.24 \pm 1.71$ & $15.23 \pm 0.03$ \\
$\mathrm{C}$ (chroma saturation) & $10.97 \pm 0.43$ & $19.01 \pm 0.69$ \\
\hline
\end{tabular}

Values are presented as mean \pm standard deviation.

Table 3. Physico-chemical characterization of almond oils of Beldi native ecotypes and Ferragnes/Ferraduel (F/F) newly introduced varieties in eastern Morocco

\begin{tabular}{lcc}
\hline Physico-chemical parameter & Beldi (B) & $\begin{array}{c}\text { Ferragnes/ } \\
\text { Ferraduel (F/F) }\end{array}$ \\
\hline Yield (\%) & $50.00 \pm 0.99$ & $57.00 \pm 0.79$ \\
Acidity (\%) & $0.40 \pm 0.007$ & $0.81 \pm 0.008$ \\
Peroxide index $\left(\right.$ meq $\left._{2} / \mathrm{kg}\right)$ & $16.39 \pm 2.95$ & $8.12 \pm 2.81$ \\
K232 & $1.85 \pm 0.01$ & $1.505 \pm 0.01$ \\
K270 & $0.09 \pm 0.002$ & $0.12 \pm 0.006$ \\
\hline
\end{tabular}

Values are presented as mean \pm standard deviation.

oils were analyzed to determine some chemical characteristics in order to suggest new end uses culinary and cosmetic applications with the best commercial added value. Almond's oil yield, acidity, peroxide index and specific UV absorbance values (K232, K270) were determined according to classical standard methods.

\section{RESULTS AND DISCUSSION}

Our results, for more than one 100 flowers color measurement of the local Beldi almonds trees, show the presence of at least two different almond ecotypes of Beldi (native genotypes) with clear differences in flower colors. The first ecotype (Group 1, Table 2) with a whitish color shows a Hue and Chroma mean values which are respectively $\mathrm{H}=47.24^{\circ}$ \& $\mathrm{C}=10.97$. However the second ecotype (Group 2, Table 2), with a pinkish color shows a lower Hue value $(\mathrm{H}=15.23)$ and a highest chroma value $(C=19.01)$. This diversity could be related to natural hybridization between the natives almond trees. The flowering of the Beldi ecotypes begin in February however the new introduced varieties $\mathrm{F} / \mathrm{F}$ start in the last week of March.

The Beldi almond nuts are generally used for almond's oil extraction. Table 3 shows physico-chemical parameters of this almond's oil of the Beldi in comparison with the F/F varieties. When compared to F/F, Beldi almond oil shows similar characteristics but with a slightly lower "almond oil" yield. 
Despite the advantages of F/F, we believe that for the diversity of crops and the conservation of biodiversity it is important to characterize this Beldi native ecotype and to conserve them for the future needs or uses in new programs of almond plantation in response to climate change.

\section{CONCLUSIONS}

The characterization of local wild almonds ecotypes could be a contribution to the conservation of biodiversity. Equally the characterization of almond's oils allows the comparison of performance of almonds varieties and to determine the performance of $\mathrm{F} / \mathrm{F}$ in this region in relation to their original sites. On the other side, these results allow the valorization of final products derived from almonds.

\section{CONFLICT OF INTEREST}

No potential conflict of interest relevant to this article was reported.

\section{REFERENCES}

Houmy N, Mansouri F, Benmoumen A, Elmouden S, Boujnah M, Sindic M, Fauconnier M L, Serghini-Caid H, and Elamrani A (2016) Characterization of almond kernel oils of five almonds varietiescultivated in eastern Morocco. In: Options Méditerranéennes, Série $A, n^{\circ}$. 119, XVI GREMPA Meeting on Almonds and Pistachios, CIHEAM Eds. Kodad O, López-Francos A, Rovira M, Socias i Company, pp. 317-321, (Zaragoza, Spain).

Lancashire Peter D, Bleiholder H, Van Den Boom T, Langeluddeke P, Stauss R, Weber E, and Witzemberger A (1991) A uniform decimal code for growth stages of crops and seeds. Ann. Appl. Biol. 119, 561-601.

Liu W, Ji J, Chen H, and Ye C (2014) Optimal color design of psychological counseling room by design of experiments and response surface methodology. PLoS One 9, e90646.

MAPM (Ministère de l'agriculture et de la peche maritime) (2014) Veilleéconomique-secteur-amandier-Note strategique, $N^{\circ} 99$ [Internet]. Available from: http://www.agriculture.gov.ma/pages/veille/veilleeconomique-secteur-amandier-juillet-2014.

Van Eck J W and Franken A A J M (1994) Distinction of white freesia (Freesia Eckl. ex Klatt) varieties by measuring colour with the aid of a chromameter. Scientia Horticulturae 60, 115-124.

Wu D and Sun D (2013) Colour measurements by computer vision for food quality control-a review. Trends Food Sci. Technol. 29, 5-20.

Wyszecki G and Stiles W S (1982) Concepts and Methods, Quantitative Data and Formulae (Vol. 2) (Wiley, New York). 